\title{
Ssciendo
}

Ethics \& Bioethics (in Central Europe), 2021, 11 (1-2), 101-114

DOI:10.2478/ebce-2021-0001

\section{Defining human-animal chimeras and hybrids: A comparison of legal systems and natural sciences}

\author{
Szymon Bokota ${ }^{1}$
}

\begin{abstract}
The article aims to present issues arising out of differences in the way that the terms chimera and hybrid are defined in legal systems and by natural sciences in the context of mixing human and animal DNA. The author analyses the different approaches to defining these terms used in various legal systems, dividing them into groups in light of conclusions reached from examining definitions used in natural sciences. The distinction is used to answer the question of which approach to definitions applied by legislators is the best way to handle the subject of humananimal organisms, given the need to balance their impact on medicine and the ethical concerns that arise.
\end{abstract}

Keywords: chimeras, hybrids, human-animal organism, legal definition, legislation

\section{Introduction}

The issue of beings with mixed human and animal elements is becoming one of the primary subjects of analysis in bioethics. We are also expecting legislators to start confronting that challenge, due to the impact of this type of research on science and the moral dilemmas connected with it. The methods of dealing with the issue of chimeras and hybrids (I will explore aspects of this distinction further below) are diverse. I want to present the various approaches to how these are defined (if at all) in several different legal systems. I decided to present examples from these systems, because in my opinion it is the best way to analyse the legislative techniques while commenting on their benefits and shortcomings. I also provide basic information on legal definitions and introduce a more general concept of mixed organisms before going on to present more specialised definitions and the consequences that result from them.

\section{Role and aspects of legal definitions}

Legal definitions are always at risk of being flawed or outdated. An endless stream of debates in the history of legal doctrine - such as the textual and intentional approach to the interpretation of disputed rules - clearly demonstrates that, despite a long history of language, law, and the tools related to them, there is no convincing way of creating perfect legal definitions. A legal definition is simply a definition that is worded by a legislator, placed in a legal act and used to give a specific meaning to a word or term used in the legal act (Malinowski, 2005, p. 215).

As Lawrence M. Solan stated: "Most battles over legal interpretation are battles about the meanings of words" (Solan, 2001, p. 244). To prevent situations that are unclear from a linguistic perspective, the legislator often introduces legal definitions. Legal definitions are useful in law for many reasons - their existence helps to correctly interpret the legislator's intention, to remove problems with the correct meaning and to make regulation more accessible (Bielska-Brodziak, 2008, pp. 159-174). They are beneficial both to the legislator and the subjects of law as a method of explaining an ambiguous word (Macagno, 2010, pp. 199-217). The structure of a definition, and simultaneously the reason for creating them rose "from two requirements that law must accommodate: logical consistency in expression and flexibility of application" (Jackson, 1985, pp. 377-386). Difficulties with law often come from the various

\footnotetext{
${ }^{1}$ University of Silesia, Katowice (Poland); szymonbokota@gmail.com; ORCID: 0000-0003-3534-4877
} 
possible understandings of a word, so legal definitions are helpful for lawyers to unify meaning. The legislator often complies with the requirement of legal certainty of a normative text, and legal definitions are a very reliable technique for avoiding confusion and manipulation (Sobolev, 2015, pp. 168-180).

In very specialised areas like biotechnology, legal definitions can also be the optimal and perhaps the only solution to introducing a preferred meaning to lawyers or subjects of law phrases used in these regulations are not a part of commonly used language, and therefore leaving them without an understandable definition could be harmful and produce endless disputes about the correct meaning. To give a better look at the importance of legal definitions and their relationship with reality, I will introduce some more statements from the doctrine. The cited examples will also point to the fact that legal definitions are not a flawless solution to all interpretational dilemmas.

One author analyses the relation between everyday language and the language of law and lawyers. He concludes that legal definitions are not ideal because legislative technique forbids them from being used too frequently and it is not possible to define every word. In addition, to introduce a legal definition is to introduce a new word, which can itself need an explanation (Opałek et al., 1969, p. 43). The verbal character of legal definitions - they are not statements of fact - is their disadvantage (Huntington, 1936, pp. 1099-1106). On a more positive note, another author considers them to be a valuable method for the legislator to make contact with the reader of a legal act. He presents three main reasons to use legal definitions:

- they give meaning to terms used in law and provide conditions to consider a situation, an entity or an object as the subject that a certain legal provision is dealing with,

- they eliminate the ambiguity of words with more than one meaning,

- $\quad$ in some cases, the legislator needs to establish a very precise meaning of the word (Zieliński, 2012, pp. 198-200).

Legal definitions are also a way not to only clarify a potentially ambiguous meaning of a word, but also to introduce a new meaning or even a completely new term (Bartoszewicz, 2018, p. 356).

As the research of Agnieszka Bielska-Brodziak shows, there are some concerns with legal definitions. Her research discusses a different understanding of them by representatives of the doctrine and the courts - for example, in one of the cited judgements, the Polish constitutional court denied that one of the provisions, despite looking like a legal definition ("A business trip is..." - File reference of the judgment: 2002 T 69/01, OTK-B 2002/2/118, ruling of Polish Constitutional Court), is not. in fact. a legal definition. The author groups concerns about legal definitions into three types:

- Problems with formulating legal definitions, placing them in regulations and recognising them as legal definitions (this problem is also underlined by Paweł Saługa (Saługa, 2008, p. 76).

- Problems with the interpretation of legal definitions.

- $\quad$ Problems with the scope of their application (Bielska-Brodziak, 2008, p. 159).

The presented information about legal definitions explains why they are so important and what their disadvantages are. No matter what is being defined, there is a considerable possibility that the legal definition will at some point not be sufficiently precise or will not fully reflect reality. This situation certainly appears in the case of beings with mixed human and animal DNA.

\section{Chimeras and hybrids}

Chimeric and hybrid organisms, being one that combines human and non-human DNA, are nowadays one of the most problematic aspects of bioethics. A chimera is an organism that contains cells, tissues, genes or even organs and body parts of another organism (Greely, 2003, 
pp. 17-20) - in the analysed case, a chimera mixes cells from a human and non-human being. A hybrid is the result of impregnating the egg cell of one species with semen from another species (Bonnicksen, 2009, p. 59).

Arguments supporting and prohibiting the creation of these are numerous on both sides. Due to the scale and complexity of the argumentation, I will restrict myself to introducing just a few key points. I selected these arguments because they show the most visible advantages and disadvantages of creating such beings. Moreover, the mentioned arguments are frequently cited in literature. They show why mixed beings have already had an impact on our reality and what their prospects are, but also arguments from the other side that underline the dangers that are discussed in bioethical discourse. For example, creating these organisms is useful for the purposes of drug testing, analysing the development of diseases (Huther, 2009, p. 83), or even, in the future, for transplanting organs from non-human donors (De Los Angeles et al., 2018, p. 335). As we can see, the main goal behind creating mixed beings is to achieve medical solutions. The history of successful experiments with implementing human genes into an animal genome starts back in the 1980s (Hanahan et al., 2007, pp. 2258-2270). The creation of animals with some human genes resulted in the possibility to fight against cancer, HIV and Ebola, or to test new methods of diagnostics (Walsh et al., 2017, pp. 187-215). These organisms are helpful in research about cells (Levine et al., 2017, p. 131), or when scientists try to understand certain human evolutionary mechanisms (Shi et al., 2019, pp. 480-481).

On the other hand, there are dilemmas like the enigmatic status of an entity that combines human and non-human DNA, the moral issue of using foetus stem cells, questions about human dignity, and the so-called "yuck factor" (Huther, 2009, p. 60). The welfare of animals with a modified genome is another problematic aspect - a good example is the case of the Beltsville pigs, which started to suffer from unexpected sicknesses after being implanted with human genes (Mann et al., 2019, p. 6).

Moreover, there are also many fields that we can consider as grey areas. These organisms can be created in different ways - less or more "moral" - and developed to different stages of life. Moreover, many ethical dilemmas are now rather theoretical, but they are starting to be revealed in our world in very real shape - like creating animals with cognitive skills closer to humans than in natural order. Considering that future human-animal organisms might possibly have better intellectual abilities (Shi et al., 2019, pp. 489-490), or even a visual resemblance to people (Bourret et al., 2016, p. 5), there are certainly a lot of doubts. As research on the arguments used in the debate about mixing human and animal DNA shows, there are multiple reasons to create mixed beings or to question the ethicality of their creation. These arguments are very varied - from moral or theological to pure consideration of negative consequences from biological view (Kwisda et al., 2020, p. 1).

The name chimera - which is more popular, because human-animal hybrids are currently much less real, and experiments involving their creation have no scientific justification - has come a long way. ${ }^{2}$ Now we consider chimeras to be a part of the natural sciences. However, the first descriptions of chimera are based on mythology, where the original Chimera was a monster combining the body parts of a lion, a goat, and a snake. A chimera in Greek mythology was a symbol of disaster (Kuře, 2009, p. 8), but was also associated with the seasons of the year

\footnotetext{
2 "At present there appears to be no rationale for creating animal-human hybrids in research. Members of the group that produced the U.K. report on humans and chimeras "were of the opinion that there is no scientific case for true interspecies hybrids" (U.K. Department of Health 2007b, Appendix H 5.7-5.9). The Wellcome Trust conveyed the same message: "full sexual hybrids between human and animal gametes would not develop beyond early preimplantation stages. It is hard to see what scientific information would be gained from such an experiment" (United Kingdom. Parliament 2007a). If there were some reason to combine human and nonhuman biological properties, this would be done by other methods such as transgenics, not by hybridization. Nevertheless, perhaps in order to protect flexibility in research, the U.K. House of Commons defeated a proposed ban on the creation of human-nonhuman hybrids in 2008 (Henderson and Elliott, 2008)" (Bonnicksen, 2009, p. 62).
} 
as something that combines different states (Graves, 2017, p. 130). The meaning of chimera evolved and by the Middle Ages had become not only an obvious representation of unholy forces, but also the name in medieval logic for an object that does not exist (Roberts, 1960, p. 274). Further sections will examine possible definitions of chimeras in interesting contexts, but now we can simplify it to an organism with cells from at least two different species.

Hybrids are not as problematic to define, though there are voices pointing to the fact that there is more than one possible understanding of hybrids in terms of mixing human and animal material (Kuře, 2009, p. 5). In fact, hybrids are not a very big part of modern research, so before examining legal definitions and definitions from natural sciences, we can consider them simply as a result of combining gametes from two different species.

In recent decades, research on chimeric entities has significantly accelerated - in 1961, Andrzej Tarkowski developed the first chimeric mice. By 2019, we had animals with superior cognitive skills due to the human gene implemented in them. The law eventually started to confront the issue of chimeras, which became an important part of medical research and ethical analysis - but it is also hard to expect that legislators will be able to answer every question associated with such a complicated matter. The law almost always tries to match progression in the real world, and we can see this also in the case of beings with mixed DNA. To name a few current examples where the legislator was forced to prepare new rules after a new situation occurred, we can mention cryptocurrency or drones. In my opinion, the consequences of developing chimeras in future can be much more complicated than in the cited examples.

The issue of mixing the DNA of different species goes much further than only aspects related to human DNA. Multiple other types of mixed organisms - like animal-animal chimeras, plant chimeras, or the effects of microbiological manipulation also have a huge impact on the shape of the world. They provide numerous advantages and disadvantages, which should be noted. However, due to the especially problematic ethical character of human-animal beings, I decided only to analyse these entities and the rules concerning them in legal acts. It is no coincidence that legislators often directly refer to chimeras and hybrids with human elements, but this will be properly presented in the later part of the article.

In later parts of the article, I will compare the regulations about chimeras and hybrids mainly definitions - in various legal systems and in natural sciences. Based on the results of this comparison, I will try to answer the question about the best possible definition of a chimera, or even the need to define a chimera in law.

\section{What do the natural sciences say?}

Natural sciences is a broad term and, due to main subject of the article, I will focus only on the selected definition of chimera and hybrid from them - I do not think that it is even possible to list every proposed definition of these organisms. We can agree that there exists a simplified and working definition - "an organism with cells from two genetically different sets of parents in its body" referring to a chimera. Despite the cited definition, concerns are also expressed about different understandings of chimeras in different sciences - "molecular biologists, geneticists, cell biologists, embryologists and other academic specialists attaching somewhat different definitions" (Bonnicksen, 2009, p. 27). The cited sentence is not the only situation when the definition of chimera, even in the context of only pure biology, is considered to be complex and multiple (Huther, 2009, p. 1).

As an example of the presented thesis that the terms chimera and hybrid have different or specialised meanings in different natural sciences, I will provide some selected definitions divided into scientific categories, with a focus on chimera, as it is more frequently discussed in terms of its precise meaning. 
Genetics: "Chimeras are hybrid products between multiple parent sequences that can be falsely interpreted as novel organisms, thus inflating apparent diversity" (Haas et al., 2011, p. 494).

Embryology: "Churchill's Medical Dictionary (1989) defines a chimera as: 'an organism composed of two or more genetically distinct cell types.' In her review of the biology of human chimeras known in 1983, Tippett (1983) says: 'a chimera has cells from two or more zygotes.' The definition in Churchill's Medical Dictionary (1989) mentions somatic mutation as a possible source of chimerism, but goes on to say: 'it occurs in humans most commonly when the blood of dizygous twins mixes in utero.' The definition in the Online Medical Dictionary (2004) does not mention mixing bloods, but offers a fusion of embryos first among the possible origins suggested" (Boklage, 2006, p. 580).

Transplantology: "The world 'chimerism' is used in this review to describe the existence in a recipient of haemopoietic elements from a donor that is allogeneic or xenogeneic to the recipient. In our terminology 'microchimerism' refers to chimerism that is not measurable by flow cytometry (FCM) (which usually has a detection limit in the range of $0.1-1 \%$ ), and requires sensitive techniques, such as a polymerase chain reaction (PCR), for its detection. 'Mixed chimerism', the topic of this review, refers to a state in which donor and host haemopoietic elements of multiple lineages coexist at levels detectable by FCM. 'Full chimerism', on the other hand, is a state in which essentially all haemopoietic elements are derived from donor stem cell inoculum" (Sykes, 2001, p. 417).

Medicine: "In medicine, an individual whose body contains different cell populations derived from different zygotes of the same or different species is defined as chimera, whereas a mosaic is an individual with two genetically distant types of cell that originates from a single zygote. In contrast to this, a hybrid is an individual composed of a single cell population derived from one zygote created by parents from two different breeding lines, races or species" (Weschka, 2009, p. 35).

As the cited examples say, there is no one correct understanding of the term "chimera" in natural sciences - a term that law must adapt in one covering meaning. In addition, there is an aspect of detailed definitions like the mentioned microchimerism. We can, however, notice the shared core in a requirement of mixing cells from different organisms. However, if we try to go further from this point, then we must admit that there is not one accepted definition of "chimera" or "hybrid" in the world of natural sciences (Kuře, 2009, p. 5). Nevertheless, when we refer to chimeras or hybrids, we have intuition about what we are debating, or we can even use some simplified, widely accepted definitions.

The legislator is forced to refer to one meaning or to enumerate situations. The wording of a legal act shapes the scope of permissible and impermissible actions. As a result, a definition forms specific orders and prohibitions, permissions and obligations. This is the main difference between legal discourse and other discourses, and that includes discourse in natural sciences. In the case of chimeras and hybrids, the simplified meaning can be used, or variants of mixed beings can be enumerated without going into dialogue with the various natural sciences. ${ }^{3}$

It hard to negate the fact that the law must confront the problem of chimeric or hybrid entities. The law is an institution that must keep up with the shape of the modern world in order to be relevant and to work. One of the methods of slowing down progression is to completely shut down some type of research, though in the aftermath, it may result in being a dead end, especially considering how much potential is in research on chimeras and hybrids. On the other hand, the moral implications of these experiments are complicated and without consensus, as was stated in the earlier part of research in this area.

\footnotetext{
${ }^{3}$ Constanze Huther dedicated a chapter to provide and discuss several arguments against chimeras and counterarguments (Huther, 2009, pp. 49-114).
} 
I do not think that the law must perfectly reflect the world of natural sciences in regulations. I do not even think it can perfectly reflect the world of natural sciences. This is not possible due to a plethora of biological meanings of chimeras or hybrids, and the fact that the law operates on a more abstract level as a set of rules - a regulation that divides mixed beings in an embryological meaning and in a genetic meaning will be illegible and would not work better than regulation with a definition that simplifies these beings. The correct definition of a chimera or hybrid is built on negating dangers and creating space for ethical and useful research on them. Of course, there is still the question as to what constitutes ethical and useful research, but that is a topic for much more extensive research. The fact is that research on chimeras and hybrids is common and it is still developing (Bonnicksen, 2009, p. 2). Now, when the issue of different definitions of human-animal beings across the sciences is underlined, we should see how the legislator is trying to define these organisms.

\section{Chimera and hybrid in legal systems - defined, not defined, over-defined?}

The issue of human-animal entities is barely touched on by the rules of the European Union, meaning that there is no definition in any directives or other acts of European law. Given that there are no explicit regulations for chimeras and hybrids in EU Law, at most we have to analyse more general regulations, such as those concerning clinical tests, public health, animal welfare or the status of human DNA. There are no binding documents even in international law (Taupnitz, 2009, pp. 450-451).

As I will show, this leads to a situation where the legislation on this topic is not uniform among European Union Member States (and, for the record, not only in Europe). The question of whether it is possible to establish a fully uniform definition of chimeras is one that only the natural sciences can answer; certainly from a legal point of view there are very different ways in which chimeras and hybrids can be presented in law. After analysing various legal systems, I isolated three options of treating these organisms in legal acts.

To begin with, there is an interesting but worrying attempt to not even to try to define a chimera or hybrid. That means the legislator is using the term "chimera" and "hybrid", introducing them to the world of law, but without defining what is meant by the term or clarifying how it is understood in the given legislative context ${ }^{4}$. Spain, where the relevant regulations - Law 14/2006 of 26 May 2006, on techniques of assisted human reproduction ${ }^{5}$ and Law 14/2007, of 3 July 2007, on Biomedical Research ${ }^{6}$ - use the term hybrid and clarify hybrid by using the word "interspecies" in order to prohibit their creation, with the exception of cases mentioned elsewhere in the legal act. This situation causes many problems even before we analyse other regulations, doctrine and jurisprudence. Without a definition of hybrid, we do not know whether the term covers also a chimera (because chimeras, as beings originating by mixing cells, are different from hybrids as products of insemination - we do not know whether the legislator was simply trying to cover a wide range of human-animal organisms in one word), which is precisely what a hybrid is, and in what context we should try to find the meaning of the term hybrid. For example - if there is no distinction between chimera and hybrid, then a person implanted with a heart valve of animal origin could be examined in light of this definition of a hybrid being. Despite a distinction in natural sciences between chimera and hybrid (Pietrzykowski, 2017, p. 48), we cannot be sure that the legislator also applies this distinction. Of course, the law cannot define every word used in acts, propose a meaning in a

\footnotetext{
${ }^{4}$ In these cases, a useful tool for interpretation can be legislative materials. Problems of their usage were comprehensively discussed by Agnieszka Bielska-Brodziak (Bielska-Brodziak, 2017).

${ }^{5}$ (Article 26 c) 7 - "The production of interspecific hybrids using human genetic material, except in the cases of currently permitted trials".

6 "The production of interspecific hybrids that use human genetic material, except for the provisions of the Law on Assisted Human Reproduction Techniques".
} 
statutory glossary or be overly enumerative. The model used in Spain causes disorientation because of the lack of a definition or other rules that give a better perspective on the nature of a mixed being. After reading the mentioned legal acts, it is only clear that hybrids are banned. On the other hand, not having a legal definition of a hybrid (or a chimera), considering developments in biotechnological research, can lead to many unclear situations. I would call this type of dealing with the issue of mixed beings the "silent approach". While the lack of a regulation or definition from legislator may be intentional, it certainly generates problems for subsequent interpreters (Bielska-Brodziak, 2017, pp. 430-431).

Another, similar, situation occurs in Germany, where the Embryo Protection Act (Gesetz zum Schutz von Embryonen (Embryonenschutzgesetz - ESchG) applies. This act is carefully presented in the opinion of the German Ethics Council, which states: "The Embryo Protection Act contains specific provisions on the formation of chimeras and hybrids only in Section 7:

\section{Section 7}

(1) prohibits the creation of a number of entities, while Section 7

(2) provides for a ban on certain transfers.

Under Section 7(1) the following, and hence also attempts at the following, are punishable offences:

1. Uniting embryos with differing genetic information to form a group of cells using at least one human embryo;

2. Combining a human embryo with a cell that contains different genetic information from that of the embryo's cells and is capable of further differentiation with that embryo; or

3. Creating an embryo capable of differentiation by fertilization of a human egg with the sperm of an animal or by the fertilization of an animal egg with human sperm" (Translation cited from the opinion of the German Ethics Council, 2011, p. 37).

The German act uses the title in section 7 - "Chimären und Hybridbildung" which means "The creation of chimeras and hybrids". While there is no clear assignment to each type of organism, there is at least clarity about what the German legislator considers a chimera and hybrid to be. It is rather obvious to rate this solution as better than in Spain, but if we analyse the cited opinion of the German Ethics Council, there are some other interesting aspects. Page 50 of the work states that the transfer of an animal organ into a human body is not a punishable offence, and this is clear, given that there is no human embryo involved. However, from a biological standpoint, after transplanting an animal organ into a human, that human technically becomes a chimera (Huther, 2009, p. 2). That is just one situation where the law clearly simplifies or even reduces the meaning of a word, though this is not necessarily a bad thing. In addition, as the German legal act proves, the legislator can even make his intent at least readable to some point without definition. While chimeras and hybrids are not defined, the reader of the law can understand exactly what types of research are banned. I consider this definition as technically a silent approach, although the rules dedicated to mixed beings makes regulation much more accessible. It is also worth noting that, in the practice of interpretation, it is assumed that a group of rules can be used to decode the legislator's intent with good results and to construct a legal definition. ${ }^{7}$

A completely opposite method to the silent approach is a wide legal definition. From the point of view of legal philosophy, this way of defining words should be termed an axiological definition, as Andrzej Malinowski states. ${ }^{8}$ Those definitions have an extensive range because

\footnotetext{
${ }^{7}$ For an example of this concept in practice, see file reference of the judgment: $20041 \mathrm{CK} 178 / 03$ of Polish Supreme Court.

8 "Axiological definitions (or in the other words: by postulates) comes down to indicating postulates that should pass every designation of defined name. If said object passes every postulate, then this is a designation of defined name, and if it does not pass even one, then this not a designation of defined name. There can be one postulate or
} 
the legislator specifies certain postulates that elements of reality should pass in order to fall under the legal definition.

The first example of an axiological definition is in the Polish Act on Infertility Treatment (Ustawa z dnia 25 czerwca 2015 r. o leczeniu niepłodności (Dz.U. 2015 poz. 1087). Definitions of chimera and hybrid are set out in Article 2, which contains a statutory glossary:

"Chimera" - a group of cells built from cells [of] differing genotypes originating in more than two specimens of the same species or different species, where one of the species is human.

"Hybrid" - a cell or group of cells formed from [human - author's addition] reproductive cells and animal reproductive cells.

As we can see, these definitions are rather wide and do not cover only an aspect of creating mixes of human and animal cells, but also experiments with more than two human "parents" for cells. A later part of the regulation, Article 25, bans the creation of chimeras and hybrids. The proposed definitions have one obvious advantage - they cover every, or almost every, possible case of hybrids and chimeras. There is not much room to discuss qualifying a new human-animal group of cells (in other words, every organism), and, in this way, we achieve clarity. On the other hand, such a rigorous and very general definition can slow down the development of biotechnologies based on interspecies creations. There are, at least, some aspects of creating chimeras or hybrids that are generally not considered to be highly unethical, such as combining a very low dosage of human cells with animal cells to analyse the development of diseases.

Another country that has taken the route of using a similarly wide definition is Switzerland, where the Federal Act on Medically Assisted Reproduction (Federal Act of 18 December 1998 on Medically Assisted Reproduction $<$ Reproductive Medicine Act, RMA $>$ ) claims in its Article 2 that; "chimera formation means the fusion of totipotent cells from two or more genetically different embryos. Embryonic cells are totipotent if they are capable of developing into any type of specialised cell" and "hybrid formation means causing a non-human sperm cell to penetrate into a human ovum, or a human sperm cell into a non-human ovum". In addition, Article 1 of the Federal Act on Medically Assisted Reproduction states that the regulation concerns humans, so "chimera" or "hybrid" in this case merges with cases of using human DNA. Another resemblance is the fact that Article 36 bans the creation of chimeras and hybrids. While the wording in the Federal Act on Medically Assisted Reproduction is a bit more precise in the case of chimeras, it stills bears a strong similarity to the Polish act, with the same advantages and disadvantages. Significantly, Article 2 also gives a definition of totipotent cells, thereby smartly evading the problem of using a specialist word "totipotent" and, despite using an axiological definition, manages to create a more limited framework than the Polish act.

Axiological definitions cover most of the possible aspects of creating mixed beings, which is useful in order to avoid doubts. In this case, there is no possible misunderstanding about what a chimera or hybrid is. It is beneficial from the perspective of potential legal liability (both civil and criminal), but I do not consider this option to be the best possible one. Axiological definitions about human-animal organisms solve a problem in too general a manner that blocks research. The legislator should think about creating space for scientific development rather than preventively banning all types of research in a situation when there is a general consensus that at least some experiments involving mixing human and animal DNA can be considered as ethical.

The legislator can, however, take an alternative approach and use enumeration to express exactly his attitude to the numerous types of experiments involving mixing human and animal material. These definitions are referred to by Andrzej Malinowski as definitions by enumeration.

many. The system of postulates should be consistent, and postulates should be unambiguous - passing these conditions allows postulates to be treated as an axiological definitions" (Malinowski, 2005, p. 229). 
The American "Human-Animal Chimera Prohibition Act" (H.R.6131 - Human-Animal Chimera Prohibition Act of 2016, s. 52), as the title suggests, bans the creation of human-animal chimeras. Due to the strict regulations this act sets out, there should also be a precise definition of chimeric entities. As the act states in $\$ 1131$ ("Definitions"), a human-animal chimera means: "(A) a human embryo into which a nonhuman cell or cells (or the component parts thereof) have been introduced to render the embryo's membership in the species Homo sapiens uncertain, (B) a chimera human/animal embryo produced by fertilizing a human egg with nonhuman sperm;

(C) a chimera human/animal embryo produced by fertilizing a nonhuman egg with human sperm;

(D) an embryo produced by introducing a human nucleus into a nonhuman egg;

(E) an embryo containing at least haploid sets of chromosomes from both a human and a nonhuman life form;

(G) a nonhuman life form engineered such that human gametes develop within the body of a nonhuman life form;

$(\mathrm{H})$ a nonhuman life form engineered such that it contains a human brain or a brain derived wholly or predominantly from human neural tissues".

Such a method of defining terms excels in covering many possible aspects, while also leaving possible space for other organisms that we can consider to be chimeras or hybrids from a natural sciences standpoint. We can look at this from two perspectives. In the first, we assume that the legislator is able to use the enumeration method to reasonably allow certain types of chimeric entities to be produced, i.e. those not classified as unethical or dangerous. On the other hand, we can argue whether, if a new "unethical" type of chimera emerges, then the regulation is incomplete and needs to be updated to once again cover the legislator's initial intention.

Another regulation that is built on enumeration is the British Human Fertilisation and Embryology Act (Human Fertilisation and Embryology Act $2008<\mathrm{c} 22>$, s. 4.), which lists types of "admixed embryo" in its Article 4A, in addition to a prohibition on mixing human and animal gametes. This is an interesting name for entities mixing different DNA, because in this way the legislator covers both chimeras and hybrids, without confronting the potentially problematic distinction. In addition, the act sets out a list of human-animal beings, from which I cite a few examples:

"an embryo created by replacing the nucleus of an animal egg or of an animal cell, or two animal pronuclei, with:

(i) two human pronuclei,

(...)

(ii) one human pronucleus and one animal pronucleus,

any embryo not falling within paragraphs (a) to (d) that contain both nuclear or mitochondrial DNA of a human and nuclear or mitochondrial DNA of an animal ("animal DNA") but in which the animal DNA is not predominant".

Despite the rather harsh wording of this act, the British system does not ban all research on chimeras - "(...) a licence would be granted dependent on the nature of the species involved and/or the extent to which such modifications are apparent: for example, a pig hybrid with <some "human genes> would be acceptable" (Beyleveld et al., 2009, p. 658). What's more, despite the enumeration, the legislator used one wider regulation in the end to have assurance that he did not leave out a situation whereby some unethical combination is not listed. However, the last case, where the embryo does not fall into the categories mentioned earlier, is still not an axiological definition, because of the specified precise criteria (combination of human and animal nuclear and mitochondrial DNA, where animal DNA is not predominant) as an addition to other mentioned possibilities of combining human and animal cells. 
The last definition representing enumerative method comes from Article 2 of the Japanese Act on Regulation of Human Cloning Techniques (Act No. 146 of 2000). ${ }^{9}$ There are three groups defined:

1. Human-Animal Hybrid Embryo,

2. Human-Animal Clone Embryo and

3. Human-Animal Chimeric Embryo.

To illustrate this method of legislation, I will cite only from the part dedicated to humananimal chimeras:

"Human-Animal Chimeric Embryo: Any of the following Embryos which is - not a HumanHuman Chimeric Embryo, Animal Embryo or Animal-Human Chimeric Embryo (including each Embryo produced successively by single or multiple splitting of such an Embryo):

(a) An Embryo produced as a result of aggregation of two or more Embryos (including an Embryo produced as a result of aggregation of such an Embryo -4- and a Somatic or Embryonic Cell) (b) An Embryo produced as a result of aggregation of an Embryo and a Somatic or Embryonic Cell (c) An Embryo produced by Fusion between an Embryonic Cell with a cell nucleus of an Embryo listed in (a) or (b) and a human or Animal Enucleated Egg".

As we can see, in additional to defining the meaning of "Human-Human Chimeric Embryo", the act insists on very detailed definitions divided into specific groups. I consider the Act on the Regulation of Human Cloning Techniques to be the most precise of the presented regulations, with a huge emphasis on not leaving any possible flaw in the regulation. The legislator knowingly enumerates which practices he regards as creating a chimera and hybrid, and even adds the category of a human-animal clone.

I think this type of definition is the most useful because it is a comprehensive representation of the legislator's intent and sets out a clear distinction of what is allowed and what is banned. In the presented situation, scientists have a plain overview of what research is permitted and, even more importantly, the type of research that is not completely prohibited.

It is, of course, possible to combine the methods of making the legal definitions set out above. One example of this is from Canadian law, because the Canadian Assisted Human Reproduction Act (Assisted Human Reproduction Act <S.C. 2004, c. 2>) uses both axiological definition and definition by enumeration. In its Article 3, which introduces definitions, a chimera is defined as:

"- an embryo into which a cell of any non-human life form has been introduced,

- an embryo that consists of cells of more than one embryo, foetus or human being".

This definition is rather general, and, indeed, a bit lacking from some possible perspectives (like introducing human cells into animal embryos). Under the act, a hybrid is defined as:

"- a human ovum that has been fertilized by a sperm of a non-human life form, - an ovum of a non-human life form that has been fertilized by a human sperm,

- a human ovum into which the nucleus of a cell of a non-human life form has been introduced, - an ovum of a non-human life form into which the nucleus of a human cell has been introduced, - a human ovum or an ovum of a non-human life form that otherwise contains haploid sets of chromosomes from both a human being and a non-human life form".

This throws up an interesting situation, because two close aspects of combining human and animal elements are resolved in two different ways - the concept of chimeras by an axiological definition while the concept of a hybrid through a definition by enumeration. In the case of chimera, the legislator decides to use a broad definition, but for hybrid he carefully sets out possible combinations leading to the creation of such a being. Both activities are banned in Article 5.

\footnotetext{
${ }^{9}$ I used translation provided by the Cabinet Secretariat. [Retrieved December 17, 2020] Available at: http://www.cas.go.jp/jp/seisaku/hourei/data/htc.pdf
} 
It is worth noting that issue of adequate definitions in legislation is discussed in the available literature. As Julian J. Koplin and Julian Savulescu observed, the creation of part-human chimeras by introducing human cells to animal embryos is not properly addressed in many legal systems. Even with definitions in legal acts, this method of producing chimeras falls between the gaps of existing legislation (Koplin et al., 2019, p. 40). Considering this observation, a question of the right way to define chimeras and hybrids is even more important.

From this point, we can summarise the gathered types of definitions (or the lack thereof) and examples from various legal systems. As a reminder, I have determined three approaches to definitions: the silent approach (used in Germany and Spain); axiological definition (used in Poland and Switzerland) and enumerative definitions (USA, UK and Japan). In all the mentioned acts, except for Canada, the legislator decided to use only one of these approaches.

The first way of handling the issue of chimeras or hybrids is simply not to define them and to use the silent approach. It is hard to rate this approach as positive, due to the very complicated status of these organisms. The terms chimera and hybrid, in the context of natural sciences or scientific experiments, are not common terms with an obvious meaning, so it is understandable that we should expect the legislator to offer at least an indication of how to interpret these words in a legal context. What is more, the average person probably does not know what a chimera is, because it is specialist knowledge. However, the German act on creating these entities can be considered as serviceable, because of listing punishable activities involving organisms, which helps to reconstruct the legislator's intent.

Another method is an axiological definition, containing such a wide range of possible chimeras and hybrids that we can even consider them to cover almost every possible way of creating these entities in ways known to modern science. This approach is much clearer that the previous one and resolves the problem of understanding when dealing with human-animal organisms. A few general postulates about what is mixed show, in broad strokes, what will fall under the scope of the definition, without the need to clarify and discuss the several specific methods of mixing animal and human cells. However, as I noted, it can be a roadblock for developing biotechnology if there is no other regulation that perhaps loosens the strictness of the mentioned definitions (such as, for example, a provision that states when a certain type of research is not considered to involve chimeras). Another possible take is the use of a lex specialis that allows human-animal organisms to be created under very special conditions without generally undermining the rules on prohibiting them without extraordinary situations (like testing a new therapy). However, in this way, the legislator risks the dispersion of the legal system if it is later decided to introduce such a lex specialis. Lex specialis are more commonly used in international law. Regardless of deciding to use a different regulation to loosen a strict ban or a lex specialis, without them axiological definitions seem to have the potential to cause a negative impact on biotechnology.

The last option for dealing with classifying chimeras and hybrids is definition by enumeration, which possibly works the best, as it clearly displays what should be considered as a chimeric or hybrid entity, and due, to this fact, we can ban it or allow certain methods of experimentation. As I mentioned, this is maybe not a perfect solution, but I consider it as the most adjusted to modern science and the reality of law. I highly favour definition by enumeration over the other two possible approaches due to its openness to scientific developments and as the amendment process is simpler, making it more responsive and better able to react to new ways of creating human-animal organisms (through the addition of a permissible or prohibited method versus the lack of a definition or a definition covering all experiments).

Then there is the solution taken by Canada, with the possibility to adapt two approaches to definitions and even mix them in one act. I do not think there is any reason to introduce another category. More pertinent would be to ask how the legal definitions (or lack of them) resonate 
with the world of science - as Aristotle stated in "Topics", these definitions are really "a phrase signifying a thing's essence" - and to ask the extent to which they must resonate with science.

\section{Conclusions}

As I presented above, legal definitions, while useful, are not always a remedy to issues of meaning. They simply cannot cover all aspects of reality, and they themselves have limitations and flaws. These limitations and flaws are especially evident in situations of a very specific nature like when dealing with purely scientific terms. We can construct them differently, as a binding description (which in some cases, despite their role as guides, we must correctly interpret) or as an enumeration. When we discuss this in the context of biotechnology, there emerges another problematic aspect - terms like "chimera" or "hybrid" are highly specialised and not in use in common language, they come from scientific journals and ethical disputes. Placing them in legal acts always requires a simplification due to the nature of law. Legal definitions can be made by enumeration or postulates, but, in many cases, these would not be as detailed as their reflection in other sciences or reality.

Law not only shapes reality, but often has to respond to it. In this respect, the law is generally playing catch-up and responds to changes in reality with an inevitable delay when attempting to cover aspects of the world that are already affecting our lives and are not sanctioned. However, the law makes boundaries for morally challenging issues. This is especially visible in the case of mixing human and animal DNA, when it can wholly ban this type of research or divide accepted and prohibited methods of creating new organisms. Definition is one of ways in which to achieve the goals of the legislator and clarify his intentions. When the legislator confronts the issue of chimeras and hybrids, he must reach for knowledge gathered in natural sciences, but cannot cite dozens of definitions from various branches. The legal definition must either be general (building upon passing postulates, like in the cited work of Malinowski) or must enumerate specific cases of mixing DNA.

Whichever of these approaches to legal definitions is used in the case of chimeric or hybrid entities, it is still better than not attempting a legal definition at all. Where the legislator adopts the silent approach and resigns from using a definition at all (which forces meaning to be teased from other sources like legislative materials), this merely confuses the interpreter and results in attempts to decode meaning from jurisprudence or the doctrine. This method cannot be recommended. I consider general definitions, as used in the Polish or Swiss acts, as an attempt to prevent the controversial results of experiments before they are conducted. In some ways this works, but in other ways it is not fully understandable from either an ethical or a scientific point of view, especially taking into consideration the circumstances for creating chimeras or hybrids, i.e. to develop medicine, not to satisfy curiosity. No matter whether we analyse human-animal organisms or other rapidly developing areas such as the use of artificial intelligence, the law can struggle with matching current trends and challenges before they have an impact. The bestknown method for both controversial and specialist terms like chimeras and hybrids is definition by enumeration. Enumeration gives scientists confidence that they can use one method of creating chimeras and hybrids and cannot use another. It makes the intent of the legislator a much clearer and compromises between the development of new, probably helpful medical technology and pausing research that can be considered as dangerous or immoral.

One thing is certain, chimeras and hybrids cannot be overlooked by legislation. The importance of research on them will only continue to grow. Other things are not so certain, namely the point to which we can develop this type of research, and where the boundaries that cannot be crossed lie. Without well-designed regulations, we will only be guessing or suffering from the blindness of the legislator. 


\section{References}

BARTOSZEWICZ, M. (2018): Definicje legalne w świetle określoności prawa [Legal definitions in the light of the specificity of the law]. In: R. Balicki \& M. Jabłoński (eds.): Dookoła Wojtek... Księga pamiątkowa poświęcona Doktorowi Arturowi Wojciechowi Preisnerowi [Around Wojtek... Commemorative Book dedicated to Doctor Artur Wojciech Preisner]. Wrocław: E-Wydawnictwo. Prawnicza i Ekonomiczna Biblioteka Cyfrowa. Wydział Prawa, Administracji i Ekonomii Uniwersytetu Wrocławskiego, pp. 355-364.

BEYLEVELD, D., FINNEGAN, T. \& PATTINSON, S. D. (2009): The regulation of hybrids and chimeras in the UK. In: J. Taupnitz \& M. Weschka (eds): CHIMBIRDS: Chimeras and Hybrids in Comparative European and International Research. Berlin: Springer, pp. 645-666. BIELSKA-BRODZIAK, A. (2008): Kłopoty z definicjami legalnymi [Problems with legal definitions]. In: O. Bogucki \& S. Czepita (eds): System prawny a porzadek prawny [Legal system and legal order]. Szczecin: Wydawnictwo Naukowe Uniwersytetu Szczecińskiego, pp. 159-174.

BIELSKA-BRODZIAK, A. (2017): Śladami prawodawcy faktycznego. Materiały legislacyjne jako narzędzie wyktadni prawa [In the footsteps of factual legislator: Legislative materials as tool of law interpretation]. Warszawa: Wolters Kluwers.

BOKLAGE, C. E. (2006): Embryogenesis of chimeras, twins and anterior midline asymmetries. In: Human Reproduction, 21(3), pp. 579-591.

BONNICKSEN, A. M. (2009): Chimeras, hybrids and interspecies research: Politics and policymaking. Georgetown: Georgetown University Press.

BOURRET, R., MARTINEZ, E., VIALLA, F., GIQUEL, C., THONAT-MARIN, A. \& DE VOS, J. (2016): Human-animal chimeras: ethical issues about farming chimeric animals bearing human organs. In: Stem Cell Research \& Therapy, 7, pp. 1-7.

DE LOS ANGELES, A., PHO, N. \& REDMOND Jr., D. E. et al. (2018): Generating human organs via interspecies chimera formation: Advances and barriers. In: Yale Journal of Biology and Medicine, 91, pp. 333-342.

GRAVES, R. (2017): The Greek myths. London: Penguin.

GREELY, H. T. (2003): Defining chimeras...and chimeric concerns. In: The American Journal of Bioethics, 3(3), pp. 17-20.

HAAS, B. J., GEVERS, D., EARLA. M., FELDGARDEN, M., WARD, D. V., GIANNOUKOS, G., CIULlA, D. M., TABBAA, D., HIGHLANDER, S., SODERGREN, E., METHE, B., DESANTIS T. Z., PETROSINO, J. F., KNIGHT, R. \& BIRREN, B. (2011): Chimeric 16S rRNA sequence formation and detection in Sanger and 454-pyrosequenced PCR amplicons. In: Genome Research, 21, pp. 494-504.

HANAHAN, D., WAGNER, E. F. \& PALMITER, R. D. (2007): The origins of oncomice: a history of the first transgenic mice genetically engineered to develop cancer. In: Genes \& Development, 21, pp. 2258-2270.

HUNTINGTON, C. (1936): A note on legal definitions. In: Columbia Law Review, 36(7), pp. 1099-1106.

HUTHER, C. (2009): Chimeras: The ethics of creating human-animal interspecifics. München: Electronic Theses of LMU Munich.

JACKSON, K. T. (1985): Definition in legal reasoning. In: Jurimetrics, 25(4) pp. 377-386.

KOPLIN, J. J. \& SAVULESCU, J. (2019): Time to rethink the law on part-human chimeras. In: Journal of Law and the Biosciences, 6(1), pp. 37-50.

KUŘE, J. (2009): Etymological background and further clarifying remarks concerning chimeras and hybrids. In: J. Taupnitz \& M. Weschka (eds.): CHIMBIRDS: Chimeras and hybrids in comparative European and international research. Berlin: Springer, pp. 7-21.

KWISDA, K., WHITE, L. \& HÜBNER, D. (2020): Ethical arguments concerning humananimal chimera research: A systematic review. In: BMC Medical Ethics, 21, pp. 1-8. 
LEVINE, S. \& GRABEL, L. (2017): The contribution of human/non-human animal chimeras to stem cell research. In: Stem Cell Research 24, pp.128-134.

MACAGNO, F. (2010): Definitions in law. In: Bulletin suisse de linguistique appliquée, 2, pp. $199-217$.

MALINOWSKI, A. (2005): Definicje legalne w prawie polskim [Legal definitions in Polish law]. In: Studia Iuridica, 44, pp. 214-240.

OPAŁEK, K. \& WRÓBLEWSKI, J. (1969): Zagadnienia teorii prawa [Issues of legal theory]. Warszawa: Państwowe Wydawnictwo Naukowe.

PIETRZYKOWSKI, T. (2018): Personhood beyond humanism: Animals, chimeras, autonomous agents and the law. Cham: Springer.

PORSDAM, S., SUN, R. \& HERMERÉN, G. (2019): A framework for the ethical assessment of chimeric animal research involving human neural tissue. In: BMC Medical Ethics, 20, pp. 19.

ROBERTS, N. (1960): A chimera is a chimera: A medieval tautology. In: Journal of the History of Ideas, 21(2), pp. 273-284.

SAŁUGA, P. (2008): Sposoby wyodrębniania definicji legalnych [Methods of isolating legal definitions]. In: Państwo i prawo, 5, pp. 76-86.

SHI, L., LUO, X., JIANG, J., CHEN, Y., LIU, C., HU, T., LI, M., LIN, Q., LI, Y., HUANG, J., WANG, H., NIU, Y., SHI, Y., STYNER, M., WANG, J., LU, Y., SUN, X., YU, H., JI, W. \& SU, B. (2019): Transgenic rhesus monkeys carrying the human MCPH1 gene copies show humanlike neoteny of brain development. In: National Science Review, 6(3), pp. 480-493.

SOBOLEV, A. (2015): Legal terminology from the rhetorical perspective: Legal genres approach. In: Pravo. Zhurnal Vysshey shkoly economiki, 3, pp. 168-180.

SOLAN, L. M. (2001): Why laws work pretty well, but not great: Words and rules. In: Law \& Social Inquiry, 26(1), pp. 243-270.

SYKES, M. (2001): Mixed chimerism and transplant tolerance. In: Immunity, 417, pp. $417-$ 424.

TAUPNITZ, J. (2009): Summary, conclusions and recommendations: Legal aspects. In: J. Taupnitz, M \& Weschka (eds.): CHIMBIRDS: Chimeras and hybrids in comparative European and international research. Berlin: Springer, pp. 433-458.

WALSH, N. C, KENNEY, L. L., JANGWALE, S., ARYEE, K. E., GREINER, D. L., BREHM, M. A. \& SCHULZ, L. D. (2017): Humanized mouse models of clinical disease. In: Annual Review of Pathology: Mechanisms of Disease, 12, pp. 187-215.

WESCHKA, M. (2009): Examples of inter-species mixtures aa. Xenotransplantation. In: J. Taupnitz \& M. Weschka (eds.): CHIMBIRDS: Chimeras and hybrids in comparative European and international research. Berlin: Springer, pp. 35-39.

ZIELIŃSKI, M. (2012): Wykładnia prawa: zasady, reguły, wskazówki [Interpretation of law: Principles, rules, advices]. Warszawa: Wolter Kluwers. 